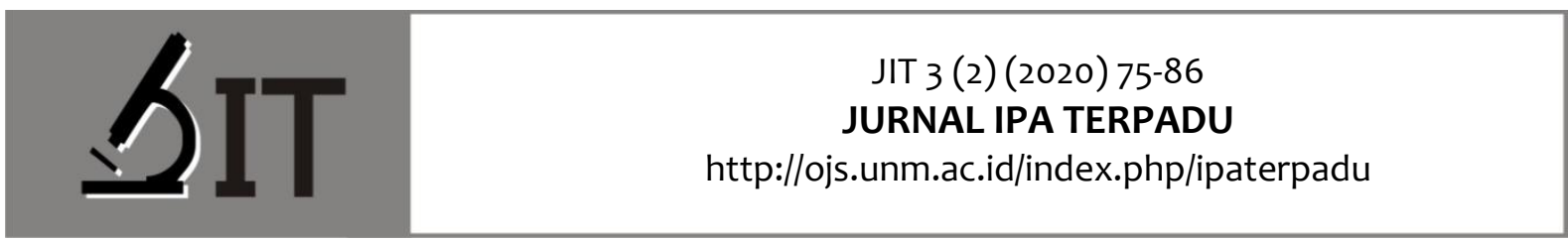

p-ISSN : 2597-8977

e-ISSN : 2597-8985

Salsabila Yusuf Saleh *) Prodi Pendidikan IPA

Nurhayani $\mathbf{H}$. Muhiddin Universitas Negeri Makassar

Muhammad Aqil Rusl Universitas Negeri Makassar

\section{STUDI KETERAMPILAN PROSES SAINS (KPS) PESERTA DIDIK KELAS VIII SMP NEGERI 12 MAKASSAR}

Abstrak: Penelitian ini bertujuan untuk mengetahui tingkat keterampilan proses sains peserta didik kelas 8 SMP Negeri 12 Makassar. Penelitian ini merupakan penelitian deskriptif kuantitatif dengan menggunakan metode penelitian survey. Populasi penelitian ini adalah seluruh peserta didik kelas VIII SMP Negeri 12 Makassar sebanyak 379 peserta didik. Sampel pada penelitian ini berjumlah 80 peserta didik dari 11 kelas yang berbeda yang dipilih melalui teknik random sampling. Instrumen penelitian berupa tes keterampilan proses sains berupa soal pilihan ganda berjumlah 25 item soal yang mewakili setiap aspek keterampilan proses sains: mengobservasi, merumuskan masalah, membuat hipotesis, merancang percobaan, mengkomunikasikan, menarik kesimpulan. Teknik pengumpulan data pada penelitian ini adalah dengan memberikan tes keterampilan proses sains kepada sampel penelitian. Analisis data dilakukan dengan menggunakan analisis deskriptif dan inferensial. Analisis deskriptif digunakan untuk menyelidiki skor rata-rata keterampilan proses sains peserta didik dan skor rata-rata peserta didik adalah sebesar 15, 24 dan berada dalam kategori sedang. Sedangkan analisis inferensial digunakan untuk mengetahui taksiran rata-rata keseluruhan populasi, diperoleh taksiran skor rata-rata untuk keseluruhan populasi berada dalam rentang 14, 41 sampai dengan 16,04 yang berarti berada dalam kategori sedang dan tinggi.

Kata Kunci: Keterampilan Proses Sains

Abstract: The purpose of this research to determine the level of science process skills in grade 8 students of SMP Negeri 12 Makassar. This research is a quantitative descriptive study using survey research methods. The population of this research was 379 students in class VIII of SMP Negeri 12 Makassar. The sample in this study amounted to 80 students from 11 different classes selected through random sampling techniques. Research instrument in the form of science process skill test in the form of multiple choice questions totaling 25 items representing each aspect of science process skills: observing, formulating the problem, make a hypothesis, design an experiment, communicating and draw conclusions. Data collection techniques in this study is to provide science process skill test to the research sample. Data analysis was performed using descriptive and inferential analysis. Descriptive analysis is used to investigate the average score of students' science process skills and the average score of students is 15,24 and is in the middle category. While inferential analysis is used to determine the estimated average overall population, the estimated average score for the entire population is in the range of 14,41 to 16,04 which means it is in the middle and high category.
Keyword: : Science Process Skills
*) Correspondence Author: salsabilays.96@gmail.com 


\section{PENDAHULUAN}

Pendidikan di Indonesia terus melakukan pembenahan menuju sistem pendidikan yang lebih efektif dan efisien. Salah satunya melalui perubahan kurikulum menjadi kurikulum 2013. Berdasarkan Permendikbud 103 Tahun 2014 pembelajaran pada kurikulum 2013 menggunakan pendekatan saintifik atau pendekatan berbasis proses keilmuan. Pembelajaran dengan pendekatan saintifik adalah proses pembelajaran yang dirancang sedemikian rupa agar peserta didik mampu secara aktif mengkonstruk konsep, hukum atau prinsip melalui tahapan-tahapan ilmiah seperti, mengamati (untuk mengidentifikasi atau menemukan suatu masalah), merumuskan masalah, mengajukan atau merumuskan hipotesis, mengumpulkan data dengan berbagai teknik, menganalisis data, menarik kesimpulan dan mengomunikasikan konsep, hukum atau prinsip yang ditemukan (Sufairoh, 2016).

Salah satu mata pelajaran wajib dalam kurikulum 2013 adalah IPA. Pembelajaran IPA dipandang memiliki dua dimensi yaitu IPA sebagai proses dan IPA sebagai produk. IPA sebagai proses mencakup sikap-sikap dan keterampilan dalam kegiatan ilmiah untuk mendorong tercapainya produk IPA (Risamasu, 2016). Keterampilan yang dimaksud adalah keterampilan proses sains.

Keterampilan proses sains (KPS) adalah kemampuan peserta didik untuk menerapkan metode ilmiah dalam memahami, mengembangkan dan menemukan suatu ilmu pengetahuan (Rahayu dan Anggraeni, 2017). KPS terdiri dari dua bagian, yakni keterampilan proses sains dasar dan keterampilan proses sains terintegrasi. Keterampilan proses sains dasar terdiri dari mengamati, mengkomunikasikan, mengklasifikasikan, menguku secara metris, menginferensi, dan memprediksi. Sedangkan keterampilan proses sains terintegrasi terdiri dari mengidentifikasi variabel, membuat sebuah tabel dari data, membuat grafik, mendeskripsikan hubungan antar variabel, mengambil dan memproses data, mendesain penyelidikan, dan melakukan penyelidikan (Rezba, 1995).

Pentingnya KPS didasarkan pada (Tawil dan Liliasari, 2014):

a. Percepatan pertambahan ilmu pengetahuan dan teknologi

b. Percepatan perubahan IPTEK

c. Pegalaman intelektual, emosional, dan fisik

d. Penanaman sikap dan nilai sebagai pengabdi pencarian abadi kebenaran ilmu

Selain itu, KPS juga penting karena merupakan salah satu keterampilan berfikir yang paling sering digunakan, sehingga individu yang tidak dapat menggunakan KPS akan mengalami kesulitan dalam kehidupan sehari-hari (Rahayu dan Anggraeni, 2017). Namun, dari hasil penelitian sebelumnya, KPS siswa di beberapa daerah di Indonesia masih sangat rendah. Sifah dan Sumarno (2016) mengatakan bahwa keterampilan proses sains siswa SMP Negeri se-Kota Semarang masih tergolong rendah. Sejalan dengan peneltian tersebut Rahman, Wahyuni dan Rifqiawati (2017) juga menyebutkan bahwa keterampilan proses sains siswa SMP Satu Atap Pulau Tunda masih tergolong rendah. Penelitian mengenai keterampilan proses sains juga dilakukan oleh Wiratana (2013) dengan hasil nilai keterampilan proses sains siswa kelas VIII di SMP Negeri 1 Negara tahun pelajaran 2012/2013 juga masih tergolong rendah. Untuk itu, peneliti tertarik untuk mengetahui tingkat keterampilan proses sains peserta didik kelas 8 di SMPN 12 Makassar.

Berdasarkan observasi awal yang dilakukan peneliti, peserta didik pada SMPN 12 Makassar kelas 8 khususnya terbiasa dalam melaksanakan praktikum IPA, sehingga peserta didik dianggap telah mengetahui aspek KPS. Kelas 8 merupakan kelas peralihan antara kelas 7 yang dianggap pengetahuannya masih dasar menuju kelas 9 yang pengetahuannya sudah mulai terintegrasi. 
Pada penelitian ini digunakan 6 aspek referensi untuk mengukur KSP siswa kelas 8 SMPN 12 Makassar yaitu: mengobservasi, merumuskan masalah, membuat hipotesis, merancang percobaan, mengomonikasikan, dan menarik kesimpulan. Materi yang diujikan adalah:

- KD 3.9 Menganalisis sistem pernapasan pada manusia dan memahami gangguan pada sistem pernapasan serta upaya menjaga kesehatan sistem pernapasan

- KD 4.9 Menyajikan karya tentang upaya menjaga kesehatan sistem pernapasan

- KD 3.12 Menganalisis sifat-sifat cahaya, pembentukan bayangan pada bidang datar dan lengkung serta penerapannya untuk menjelaskan proses penglihatan manusia, mata serangga, dan prinsip kerja alat optik

- KD 4.12 Menyajikan hasil percobaan tentang pembentukan bayangan pada cermin dan lensa

Aspek-aspek tersebut dipilih berdasarkan analisis kurikulum 2013 untuk kelas 8, sedangkan materi yang diujikan dipilih berdasarkan analisis kompetensi dasar dan pengalaman mengajar guru IPA kelas 8 SMPN 12 Makassar.

\section{METODE}

Pada penelitian ini metode yang digunakan adalah metode survey dan pengumpulan data dilakukan dengan menggunakan tes keterampilan proses sains. Populasi dalam penelitian ini adalah seluruh peserta didik kelas VIII SMP SMPN 12 Makassar yang berjumlah 379 siswa dan tersebar di 11 kelas yang berbeda. Sampel penelitian adalah peserta didik kelas 8 yang diambil secara random sampling dari seluruh populasi. Teknik menentukan jumlah sampel menggunakan rumus Slovin adalah sebagai berikut (Sugiyono, 2014):

$\mathrm{n}=\frac{N}{1+N e^{2}}$

\section{Keterangan:}

$\mathrm{n} \quad$ : Ukuran sampel/ jumlah sampel

$\mathrm{N}$ : Ukuran populasi

e : Presentase kelonggaran ketelitian kesalahan pengambilan sampel yang masih bisa ditolerir

Berdasarkan hasil perhitungan menggunakan rumus Slovin tersebut maka sampel yang digunakan minimal 79 peserta didik. Pada penelitian ini digunakan sampel sebanyak 80 peserta didik. Instrumen penelitian yang digunakan dalam penelitian ini yaitu soal keterampilan proses sains. Soal keterampilan proses sains berupa test objektif berupa soal pilihan ganda sebanyak 25 butir soal yang terdiri dari empat pilihan jawaban. Keseluruhan soal mencakup 6 aspek keterampilan proses sains yang di tunjukkan pada table 1.1. Soal tersebut kemudian di validasi oleh ahli dan guru IPA SMPN 12 Makassar. Hasil analisis data ditampilkan dalam bentuk skor rata-rata, standar deviasi, skor maksimun, skor minimum, distribusi frekuensi dan taksiran rata-rata. Skor ratarata didapatkan dengan menggunakan persamaan sebagai berikut (Sudjana N. , 2005): 
$\bar{X}=\frac{\sum x_{i}}{n}$

Keterangan:

$\bar{X}$ : Rata-rata nilai yang diperoleh

$n$ : Jumlah sampel

$x_{i}:$ Skor keterampilan proses sains

Berikut ini Tabel 1 yang menunjukkan indikator soal untuk setiap aspek keterampilan Proses Sains.

Tabel 1. Aspek Keterampilan Proses Sains dan Indikator Soal

\begin{tabular}{|c|c|c|c|}
\hline No & $\begin{array}{l}\text { Aspek Keterampilan } \\
\text { Proses Sains }\end{array}$ & Indikator Soal & $\begin{array}{l}\text { Nomor } \\
\text { Soal }\end{array}$ \\
\hline 1. & Mengobservasi & $\begin{array}{l}\text { - Menggunakan indra pengelihatan dalam mengamati untuk } \\
\text { menentukan pernyataan yang benar }\end{array}$ & $\begin{array}{l}1,2,3,14 \\
15\end{array}$ \\
\hline 2. & Merumuskan Masalah & $\begin{array}{l}\text { - Rumusan masalah menyatakan antara variabel manipulasi } \\
\text { dan variabel respon } \\
\text { - Menyusun perumusan masalah dengan jelas berdasarkan } \\
\text { kesimpulan dari percobaan yang dilakukan }\end{array}$ & $4,5,16,18$ \\
\hline 3. & Menyusun Hipotesis & $\begin{array}{l}\text { - Hipotesis menunjukkan hubungan antara variabel manipulasi } \\
\text { terhadap variabel respon } \\
\text { - Menyatakan gambaran logis dari suatu hubungan yang } \\
\text { dapat diuji } \\
\text { - Merumuskan hipotesis berdasarkan rumusan masalah yang } \\
\text { - Misajikan }\end{array}$ & $6,8,17,19$ \\
\hline 4. & Merancang Percobaan & $\begin{array}{l}\text { - Desain percobaan disusun secara sistematis } \\
\text { - Menemukan alat/bahan/sumber yang akan digunakan } \\
\text { - Mendesain percobaan berdasarkan alat dan bahan yang } \\
\text { disajikan }\end{array}$ & $\begin{array}{l}7,9,10,20, \\
21\end{array}$ \\
\hline 5. & Mengkomunikasikan & $\begin{array}{l}\text { - Menggambarkan/memberikan data hasil percobaan dengan } \\
\text { grafik atau tabel atau diagram } \\
\text { - Membaca informasi dalam grafik, tabel maupun diagram }\end{array}$ & $\begin{array}{l}11,12,22 \\
23\end{array}$ \\
\hline 6. & Menarik Kesimpulan & $\begin{array}{l}\text { - Kesimpulan ditarik untuk menjawab masalah percobaan } \\
\text { - Menarik kesimpulan berdasarkan data hasil percobaan }\end{array}$ & $13,24,25$ \\
\hline
\end{tabular}

Untuk menghitung standar deviasi digunakan persamaan sebagai berikut (Tiro, 2015):

$S=\sqrt{\frac{\sum(X-\bar{X})^{2}}{n-1}}$

Keterangan:

$\mathrm{S}$ : Nilai standar deviasi

$X$ : Skor keterampilan proses sains

$\mathrm{n}$ : Jumlah sampel

$\bar{X}$ : Rata-rata nilai yang diperoleh

Tingkatan kategori skor keterampilan proses sains digunakan untuk mengetahui tingkatan kategori keterampilan proses sains keseluruhan ditunjukkan pada Tabel 2 berikut. 
Tabel 2. Interpretasi Kategori Keterampilan Proses Sains Peserta Didik

\begin{tabular}{ccc}
\hline No & Interval Skor & Kategori \\
\hline 1. & $21-25$ & Sangat tinggi \\
2. & $16-20$ & Tinggi \\
3. & $11-15$ & Sedang \\
4. & $6-10$ & Rendah \\
5. & $0-5$ & Sangat Rendah \\
\hline ber: Dimodifikasi dari Rahayu dan anggraeni (2017)
\end{tabular}

Adapun penaksiran rata-rata skor digunakan untuk membuat taksiran (pendugaan) yang sangat diperlukan dalam konsep probabilitas karena sangat berguna dalam pembuatan keputusan pada kondisi ketidakpastian. Untuk mendapatkan taksiran rata-rata skor digunakan rumus berikut (Tiro, 2015):

$$
\bar{x}-t_{p} \frac{s}{\sqrt{n}} \sqrt{\frac{N-n}{N-1}} \leq \mu \leq \bar{x}+t_{p} \frac{s}{\sqrt{n}} \sqrt{\frac{N-n}{N-1}}
$$

Keterangan:

$\bar{x}$ : Rata-rata skor

$\mathrm{S}:$ Standar deviasi

$\mathrm{N}$ : Jumlah populasi

$\mathrm{N}$ : Jumlah sampel

$\mu$ : Rerata skor

Statistik $\mathrm{t}$ di atas memiliki derajat kebebasan yaitu $\mathrm{dk}=\mathrm{n}-1 \mathrm{dan} \mathrm{p}=(1+\mathbb{\gamma}) / 2$

\section{HASIL DAN PEMBAHASAN}

\section{Hasil Penelitian}

Hasil analisis data menunjukkan karakteristik keterampilan proses sains peserta didik kelas VIII SMP Negeri 12 Makassar. Statistik data keterampilan proses sains peserta didik ditunjukkan pada Tabel 3 .

Tabel 3. Statistik Data Keterampilan Proses Sains Peserta Didik

\begin{tabular}{clc}
\hline No & \multicolumn{1}{c}{ Statistik } & Data \\
\hline 1 & Jumlah populasi & 379 \\
2 & Jumlah sampel & 80 \\
3 & Skor tertinggi ideal & 25 \\
4 & Skor terendah ideal & 0 \\
5. & Skor tertinggi empirik & 23 \\
6. & Skor terendah empirik & 5 \\
7. & Skor rata-rata & 15,24 \\
8. & Standar deviasi & 4,9 \\
9. & Varians & 24,13 \\
\hline
\end{tabular}


Berdasarkan Tabel 3, diperoleh skor total keterampilan proses sains peserta didik kelas 8 SMPN 12 Makassar adalah sebesar 15, 24, di mana skor tersebut berada dalam tingkat kategori sedang. Kategori sedang tersebut berada dipertengahan kategori tinggi dan rendah. Namun sebenarnya telah mendekati kategori tinggi, dimana skor 15, 24 telah mendekati rentang skor untuk kategori tinggi yaitu skor 16 - 20. Jika diberlakukan kepada seluruh populasi dengan menggunakan rumus taksiran rata-rata, maka rerata skor akan berada pada rentang 13,91 sampai dengan 16,77, jika dikategorikan berdasarkan Tabel 4 maka seluruh populasi berada dalam kategori sedang dan tinggi.

Tabel 4. Kategori Keterampilan Proses Sains Peserta Didik

\begin{tabular}{cccc}
\hline Interval & Kategori & Frekuensi & Persentase (\%) \\
\hline $0-5$ & Sangat rendah & 10 & 12,50 \\
$6-10$ & Rendah & 30 & 37,50 \\
$11-15$ & Sedang & 25 & 31,25 \\
$16-20$ & Tinggi & 14 & 17,40 \\
$21-25$ & Sangat tinggi & 1 & 1.25 \\
\hline
\end{tabular}

Pada observasi awal telah diperoleh informasi bahwa peserta didik merasa mampu melaksanakan aspek-aspek keterampilan proses sains. Peserta didik kelas VIII SMPN 12 Makassar cukup sering melaksanakan percobaan/ peraktikum. Hal ini yang menjadikan peserta didik memiliki keterampilan proses sains yang cukup baik. Hal ini didukung pernyataan Satriani, Taiyeb dan Mu'nisa bahwa terhadap hubungan positif antara pelaksanaan praktikum dengan keterampilan proses sains peserta didik (Satriani, Taiyeb \& Mu'nisa, 2018).

Hasil analisis data kemudian digunakan untuk menghitung taksiran rata-rata. Hasil perhitungan menunjukkna rerata skor peserta didik akan berada dalam rentang 13,91 sampai dengan 16,77 . Sehingga jika dikategorikan akan berada dalam kategori sedang dan tinggi.

Berdasarkan penelitian Sukarno, Permanasari, dan Hamidah menyatakan bahwa rendahnya keterampilan proses sains peserta didik dapat disebabkan oleh banyak faktor, diantaranya adalah: 1) rendahnya kemampuan keterampilan proses sains pendidik; 2) kurangnya bahan ajar yang mengembangkan dan meningkatkan keterampilan proses sains peserta didik; 3) masih adanya uji kompetensi yang hanya berfokus pada penggunaan konsep ilmiah saja; 4) kurang jelasnya bimbingan bagi pendidik bagaimana melakukan penilaian dan pengembangan keterampulan proses sains kepada peserta didik; 5) kegiatan belajar mengajar selama ini masih bersifat tradisional, sehingga siswa kurang dalam mengeksplorasi keterampilan proses sains (Sukarno, Permanasari, dan Hamidah, 20013). Tidak jauh berbeda dari peneliti sebelumnya, factor-faktor lain rendahnya keterampilan proses sains adalah: 1) tidak tepatnya metode atau model pembelajaran yang diberikan; 2) kurangnya pengetahuan guru terkait keterampilan proses sains dan sekolah jarang memberikan pelatihan terkait pembelajaran terhadap guru (Rahman, Wahyuni dan Rifqiawati, 2017); 3) kurang lengkapnya sarana dan prasarana yang dimiliki sekolah; 4) kurangnya pembiasaan melakukan keterampilan proses sains pada proses pembelajaran oleh guru; 5) serta kurangnya rasa ingin tahu dan motivasi peserta didik saat belajar (Sifah dan Sumarno, 2016); 6) guru tidak terampil dalam menyusun LKPD 7) guru IPA masih menggunakan tes kognitif sebagai satu-satunya instrument untuk menilai mata pelajaran IPA (Hamadi, 2018).

Pentingnya peran guru dalam proses pembeajaran disebutkan oleh Rustaman adalah sebagai penyampai informasi, pengelola kelas, fasilitator, mediator dan evaluator (Hamadi, 2018), sehingga pemahaman guru terhadap kemampuan keterampilan proses sains diperlukan sebagai dasar untuk dapat mendukung dan mengembangkan keterampilan proses sains peserta didik. 
Faktor yang menghambat guru menerapkan keterampilan proses sains selama pembelajaran ialah: 1) waktu belajar mengajar yang kurang sementara materi IPA cukup banyak; 2) latar belakang peserta didik yang berbeda-beda; 3) keterbatasan laboratorium keterampilan proses sains (Hamadi, 2016); 4) Guru belum mampu membuat sendiri LKPD IPA; 5) guru belum mampu membuat instrument KPS (Diella, Ardiansyah dan Suhendi, 2019).

Dari faktor yang menghambat guru dalam mengembangkan keterampilan proses sains yang dapat dilakukan ialah: 1) mengadakan pelatihan keterampilan proses sains sains secara berkala kepada guru, baik untuk pengembangan LKPD IPA khususnya keterampilan proses sains, pengembangan instrument keterampilan proses sain ataupun model atau metode yang mampu meningkatkan keterampilan proses sains; 2) guru sebaiknya mempersiapkan sebaik mungkin rancangan pembelajaran agar materi, metode dan waktu mengajar dapat disesuaikan; 3) guru terus membiasakan menerapkan keterampilan proses sains pada pembelajaran IPA; 4) guru harus terus menstimulasi dan memotivasi peserta didik agar keterampilan proses sainsnya terus berkembang; 5) adanya instrument khusus untuk menilai keterampilan proses sains, agar peserta didik mampu dikembangkan secara terarah keterampilan proses sainsnya.

Adapun hasil tes keterampilan proses sains untuk setiap aspek adalah sebagai berikut:

a. Mengobservasi

Hasil obeservasi awal menunjukkan peserta didik tidak mengalami kendala untuk melakukan observasi. Peserta didik telah terbiasa melakukan pengamatan sehingga tidak ada kendala. Hal ini sejalan dengan penelitian Suja yang menyatakan bahwa keterampilan untuk melakukan observasi, menginterpretasikan data dan mengklasifikasikan data menjadi mantap pada anak kelas VI (usia 11 - 12 tahun) (Rahman, Wahyuni dan Rifqiawati, 2017).

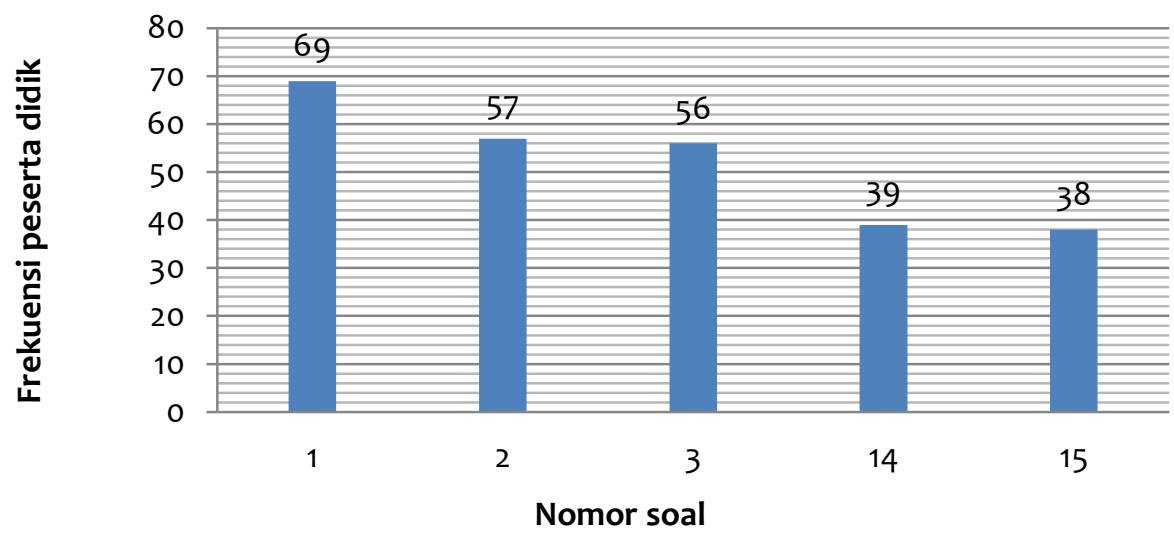

\section{Gambar 1. Frekuensi Peserta Didik Pada Aspek Mengobservasi}

Berdasarkan Gambar 1 diketahui bahwa frekuensi tertinggi pada aspek ini berada pada nomor 1 dengan indikator materi menggunakan indera pengeliatan dalam mengamati gambar bronkus untuk menentukan ciri-ciri saluran bronkus saat terjadi asma dan frekuensi terendah pada nomer 15 dengan indikator materi menggunakan indera pengeliatan dalam mengamati gambar bayangan pada cermin untuk menentukan sifat bayangan pada cermin untuk menentukan sifat bayangan yang dihasilkan. 


\section{b. Merumuskan Masalah}

Keterampilan merumuskan masalah merupakan suatu dugaan yang dapat diuji bagaimana dan mengapa sesuatu terjadi (Hamadi, 2018), diperlukan pemberian motivasi dan stimulus untuk meningkatkan rasa ingin tahu peserta didik (Sifah dan Sumarno, 2016). Beberapa peserta didik mengaku tidak pernah merumuskan masalah baik pada pembelajaran atau pada saat melaksanakan praktikum. Mereka belum pernah diajarkan atau mengetahui baagaimana merumuskan masalah. Namun beberapa diantara mereka juga dapat merumuskan masalah karena telah terbiasa dilatih oleh guru, baik secara langsung atau telah tersedia didalam LKPD.

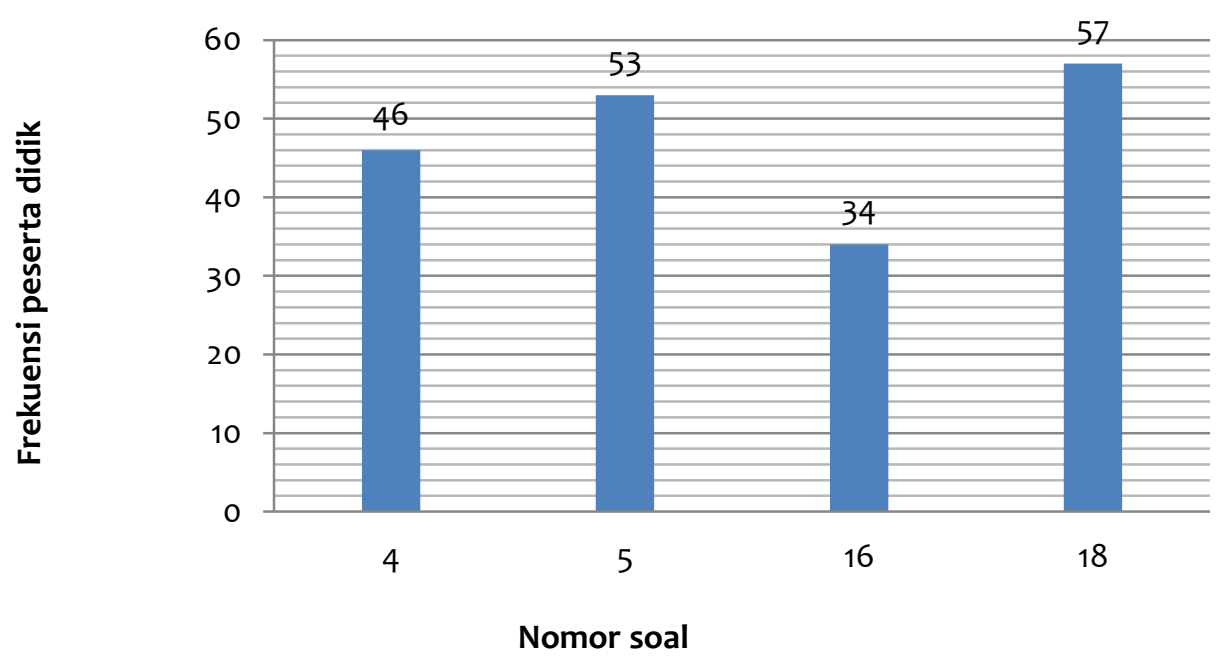

\section{Gambar 2. Frekuensi Peserta Didik Pada Aspek Merumuskan Masalah}

Hasil pengujian keterampilan proses sain aspek merumuskan masalah menunjukkan frekuensi tertinggi berada pada nomer 18 dengan indikator materi menunjukkan hubungan antara variabel manipulasi dan variabel respon. Frekuensi terendah pada nomer 16 dengan indikator materi menyusun rumusan masalah dengan jelas berdasarkan kesimpulan dari percobaan yang dilakukan (Gambar 2).

\section{c. Membuat Hipotesis}

Pada saat wawancara beberapa peserta didik mengatakan bahwa hasil praktikum atau percobaan telah lebih dahulu diberitahukan oleh guru sehingga peserta didik tidak lagi menduga hasil dari suatu percobaan. Namun beberapa peserta didik lain memberi pernyataan berbeda bahwasannya peserta didik biasanya diminta untuk menduga hasil sebelum dilaksanakan praktikum atau percobaan. Peserta didik akan memperkirakan hasil berdasarkan apa yang mereka ketahui sebelumnya dari materi yang mereka pelajari atau pengalaman yang mereka miliki. 


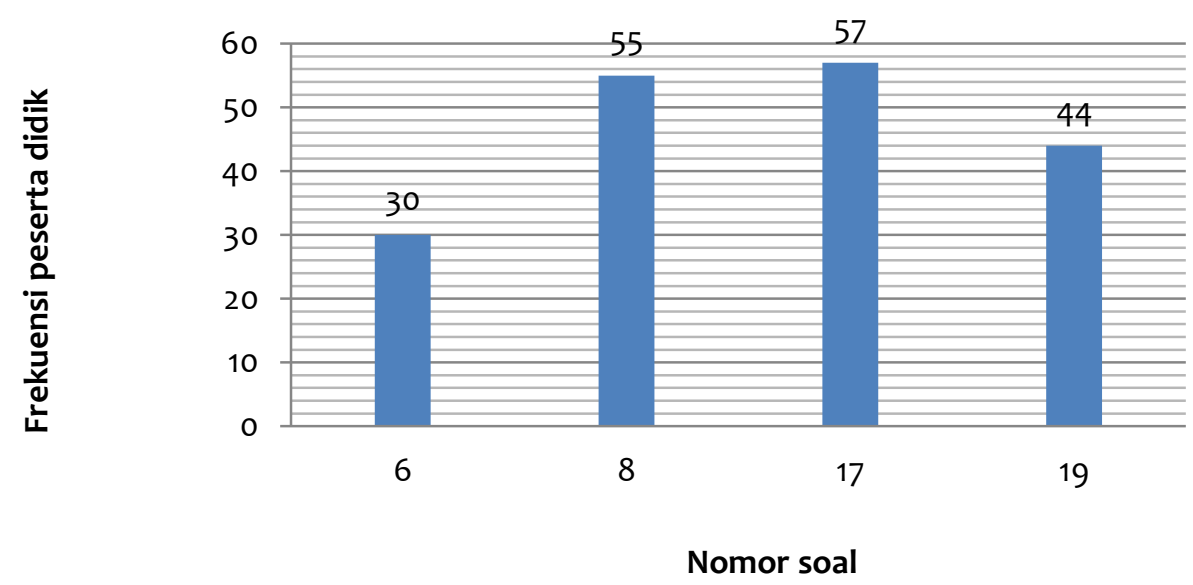

\section{Gambar 3. Frekuensi Peserta Didik Pada Aspek Membuat Hipotesis}

Gambar 3 menunjukkan frekuensi peserta didik yang benar dalam menjawab soal aspek membuat hipotesis lebih tinggi pada materi cahaya (soal no 17). Sedangkan, frekuensi terendah pada soal nomor 6 dengan indikator materi menunjukkan hubungan antara variabel manipulasi terhadap variabel respon.

\section{d. Merancang Percobaan}

Pada observasi yang dilakukan oleh peneliti diketahui bahwa peserta didik banyak yang belum mampu merancang percobaan. Hal ini juga ditunjukkan pada penelitian Sifah dan Sumarno (2016) bahwa keterampilan proses sains siswa SMPN se-Kota Semarang masih rendah pada aspek merancang percobaan.

Kurang mampunya peserta didik dalam merancang percobaan dikarenakan percobaan yang dilakukan biasanya telah tersusun dan tersedia di dalam laboratorium, guru mengintruksikan langkah-langkah kerja atau guru membantu peserta didik dalam melaksanakan praktikum. Padahal seharusnya eksperimen/ percobaan dilakukan siswa dengan merangkai sendiri alat dan bahan, menggunakan alat dan bahan sesuai prosedur dan merapikan kembali setelah digunakan (Hamadi, 2016).

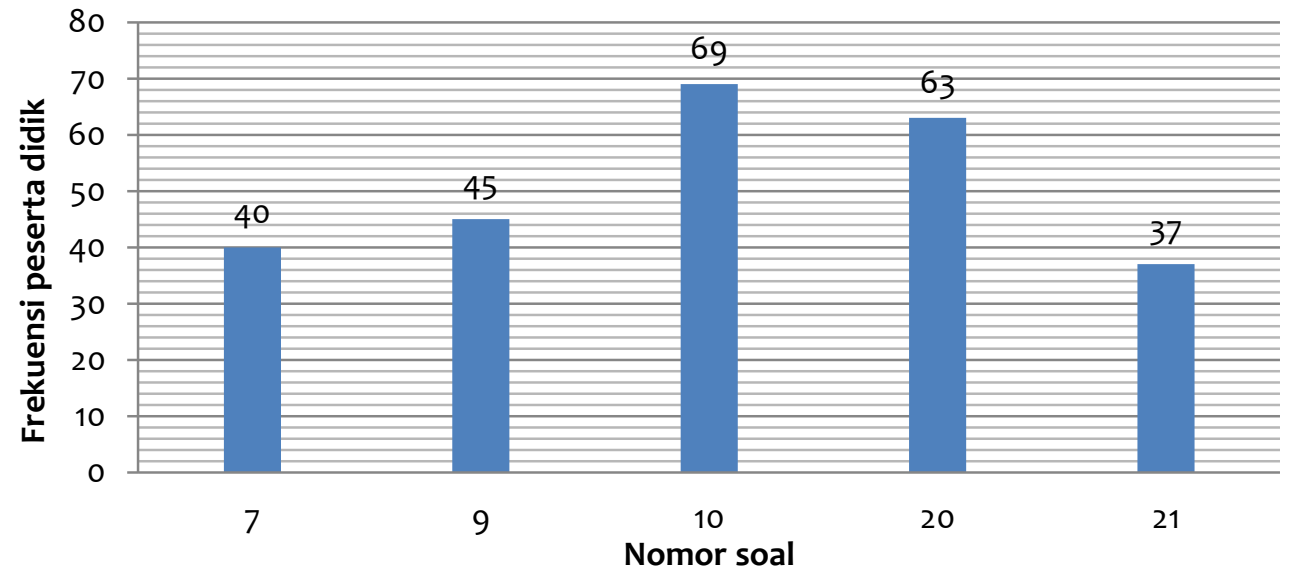

Gambar 4. Frekuensi Peserta Didik Pada Aspek Merancang Percobaan 
Gambar 4 menunjukkan frekuensi tertinggi dalam aspek merancang percobaan berada pada soal nomer 10 dengan indikator materi menentukan alat/ bahan/ sumber yang akan digunakan. Adapun frekuensi terendah pada soal nomor 21 dengan indikator materi mendesain percobaan secara sistematis.

e. Mengkomunikasikan

Aspek mengkomunikasikan, menurut kurniawati keterampilan komunikasi adalah keterampilan menyampaikan hasil belajar kepada orang lain dalam bentuk tulisan, gambar, gerak, tindakan atau penampilan (Sifah dan Sumarno, 2016).

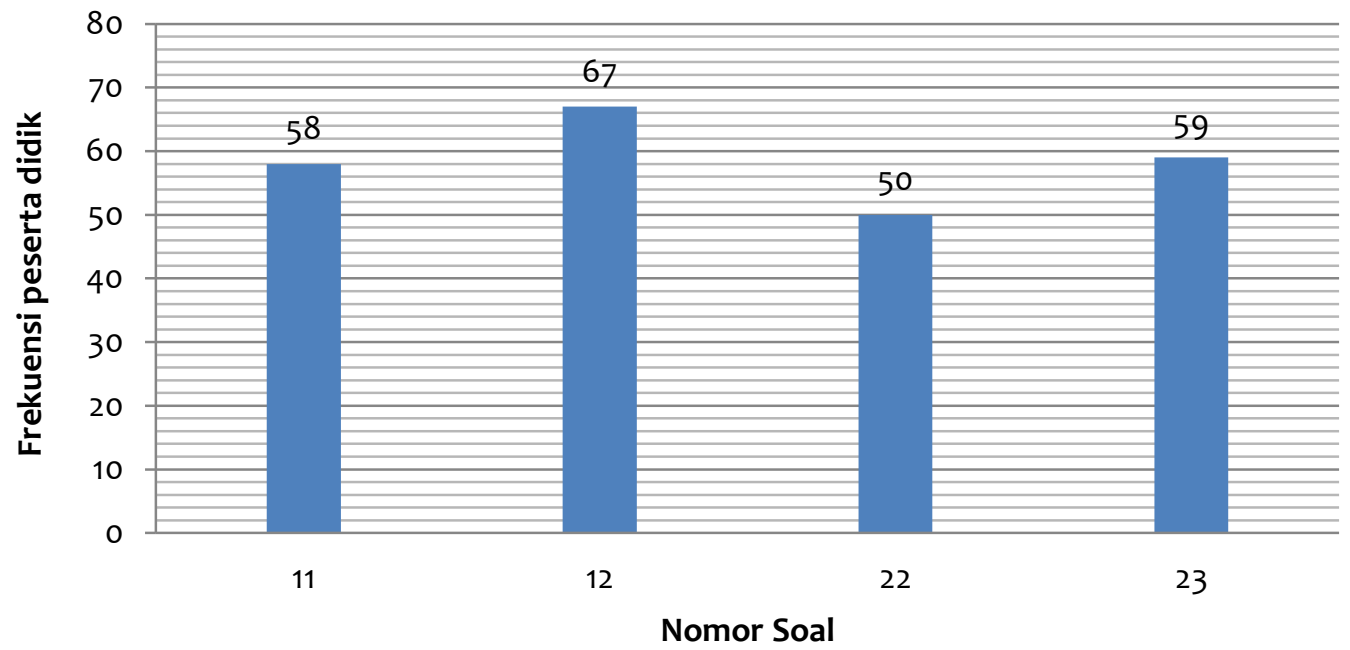

Gambar 5. Frekuensi Peserta Didik Pada Aspek Mengomonikasikan

Hasil observasi awal menunjukkan peserta didik telah terbiasa untuk menyampaikan hasil belajar dalam bentuk tulisan, presentasi, diskusi ataupun mengubah bentuk data. Namun beberapa diantara peserta didik mengaku belum mampu untuk mengubah bentuk data menjadi bentuk data yang lainnya contohnya kedalam bentuk tabel, diagram atau grafik.

Pada aspek mengomonikasikan, frekuensi peserta didik yang benar dalam menjawab soal melebihi untuk setiap item soal melebihi 50\% dari total sampel peserta didik. Frekuensi tertinggi berada pada soal nomer 12 dengan indikator materi menggambarkan data hasil percobaan dalam bentuk tabel. Frekuensi terendah pada soal nomer 21 dengan indikator materi membaca informasi dalam bentuk grafik.

\section{f. Menarik Kesimpulan}

Pada aspek menarik kesimpulan peserta didik telah terbiasa melakukan kegiatan menarik kesimpulan pada akhir pembelajaran. Setelah melakukan percobaan atau pembelajaran dikelas yang tanpa percobaan, peserta didik diminta oleh pendidik untuk menyimpulkan hasil percobaan atau menyimpulkan hasil dari pembelajaran. Peserta didik akan membuat kesimpulan secara mandiri ataupun secara berkelompok melalui diskusi. Sehingga peserta didik tidak merasa kesulitan dalam menarik kesimpulan. 


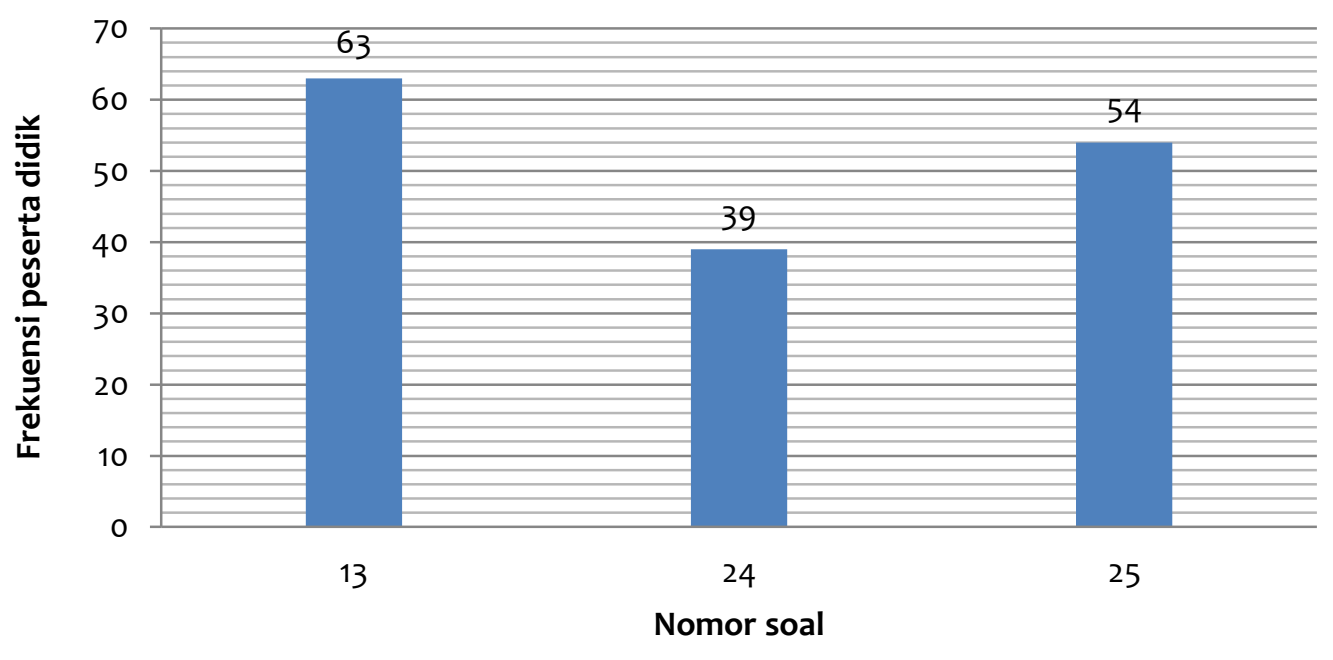

Gambar 6. Frekuensi Peserta Didik Pada Aspek Menarik kesimpulan

Menurut peserta didik, mereka terbiasa melakukan kegiatan menarik kesimpulan pada akhir pembelajaran. Setelah melakukan percobaan atau pembelajaran dikelas yang tanpa percobaan, peserta didik diminta oleh pendidik untuk menyimpulkan hasil percobaan atau menyimpulkan hasil dari pembelajaran. Peserta didik akan membuat kesimpulan secara mandiri ataupun secara berkelompok melalui diskusi. Sehingga peserta didik tidak merasa kesulitan dalam menarik kesimpulan.

Frekuensi tertinggi berada pada soal nomer 13 dengan indikator materi menarik kesimpulan berdasarkan gambar grafik. Frekuensi terendah pada soal nomor 24 dengan indikator materi menarik kesimpulan berdasarkan data hasil percobaan dalam bentuk tabel.

\section{KESIMPULAN}

Berdasarkan hasil penelitian dan pembahasan yang telah dikemukakan, maka diperoleh kesimpulan mengenai tingkat keterampilan proses sains peserta didik kelas VIII SMPN 12 Makassar secara rata-rata berada pada skor 15, 3 dan berada dalam kategori cukup. Sedangkan untuk ratarata populasi berada pada kisaran 13, 91 -16, 77 dan berada dalam kategori sedang dan tinggi.

\section{DAFTAR PUSTAKA}

Diella, D., Ardiansyah, R., Suhendi, H. Y. (2019). Pelatihan Pengembangan LKPD Berbasis Keterampilan Proses Sains (KPS) dan Penyususnan Instrument Asesmen KPS Bagi Guru IPA. Jurnal Publikasi Pendidikan, Vol. 9, No. 1.

Hamadi, A. A. L. (2018). Pemahaman Guru Terhadap Keterampilan Proses Sains (KPS) dan Penerapannya Dalam Pembelajaran IPA SMP Di Salatiga. Jurnal Pendidikan Sains dan Matematika, Vol. 6, No. 2.

Rahayu, A. H., \& Anggraeni, P. (2017). Analisis Profil Keterampilan Proses Sains Siswa Sekolah Dasar di Kabupaten Sumedang. Jurnal Pesona Dasar, Vol. 5, No. 2.

Rahman, A., Wahyuni, I., \& Rifqiawati, I. (2017). Profil Keterampilan Proses Sains dan Sikap Ilmiah Siswa di SMP Satu Atap Pulau Tunda. SEJ, Vol. 7, No. 1. 
Rezba, J. R. (1999). Learning and Asessing science process skill Four Edition. Kendall: Hunt Publishing Company.

Risamasu, P. V. M. (2016). Peran Pendekatan Keterampilan Proses Sains dalam Pembelajaran IPA. Prosiding Seminar Nasional Pendidikan, Jayapura 2016.

Satriani., Taiyeb, A. M., Mu'nisa, A. (2018). Analisis Hubungan Pelaksanaan Praktikum Dengan Keterampilan Proses Sains dan Hasil Belajar Biologi Peserta Didik SMA Negeri di Kota Bulukumba. Prosiding Seminar Nasional Biologi dan Pembelajarannya.

Sifah, L., \& Sumarno. (2016). Profil Keterampilan Proses Sains (KPS) Siswa SMP Negeri Se-Kota Semarang. Prosiding Seminar Nasional.

Sudjana, N. (2005). Metode Statistika. Bandung: PT. Tarsito

Sufairoh. (2016). Pendekatan Saintifik \& Model Pembelajaran K-13. Jurnal Pendidikan Profesional, Vol. 5, No. 3 .

Sukarno, Permanasari, A., \& Hamidah, I. (2013). Profil Keterampilan Proses Sains Siswa di SMP Negeri (studi kasus di Jambi). Jurnal internasional teknik ilmiah dan penelitian (IJSER).

Tawil, M., \& Liliasari. (2014). Keterampilan-keterampilan sains dan implementasinya dalam pembelajaran IPA. Makassar: UNM

Tiro, M. A. (2015). Dasar-dasar statistika edisi ketiga. Makassar: Andira Publisher

Wiratana, I. K., Sadial, W., \& Suma, K. (2013). Pengaruh model pembelajaran koperatif tipe investigasi kelompok (group investigation) terhadap keterampilan proses dan hasil belajar sains siswa SMP. Jurnal Program Pascasarjana Universitas Pendidikan Ganesha Program Studi IPA, Vol. 3, No. 2.

\section{Salsabila Yusuf Saleh \\ Mahasiswa Program Studi Pendidikan IPA FMIPA UNM, aktif melakukan penelitian pada bidang Pendidikan IPA, dapat dihubungi melalui pos-el: salsabilays.96@gmail.com.}

\section{Nur Hayani H. Muhiddin}

Dosen Program Studi Pendidikan IPA FMIPA UNM, aktif melakukan penelitian pada bidang Pendidikan IPA.

\section{Muhammad Aqil Rusli}

Dosen Program Studi Pendidikan IPA FMIPA UNM, aktif melakukan penelitian pada bidang Pendidikan IPA. 